Tracing the Veins 


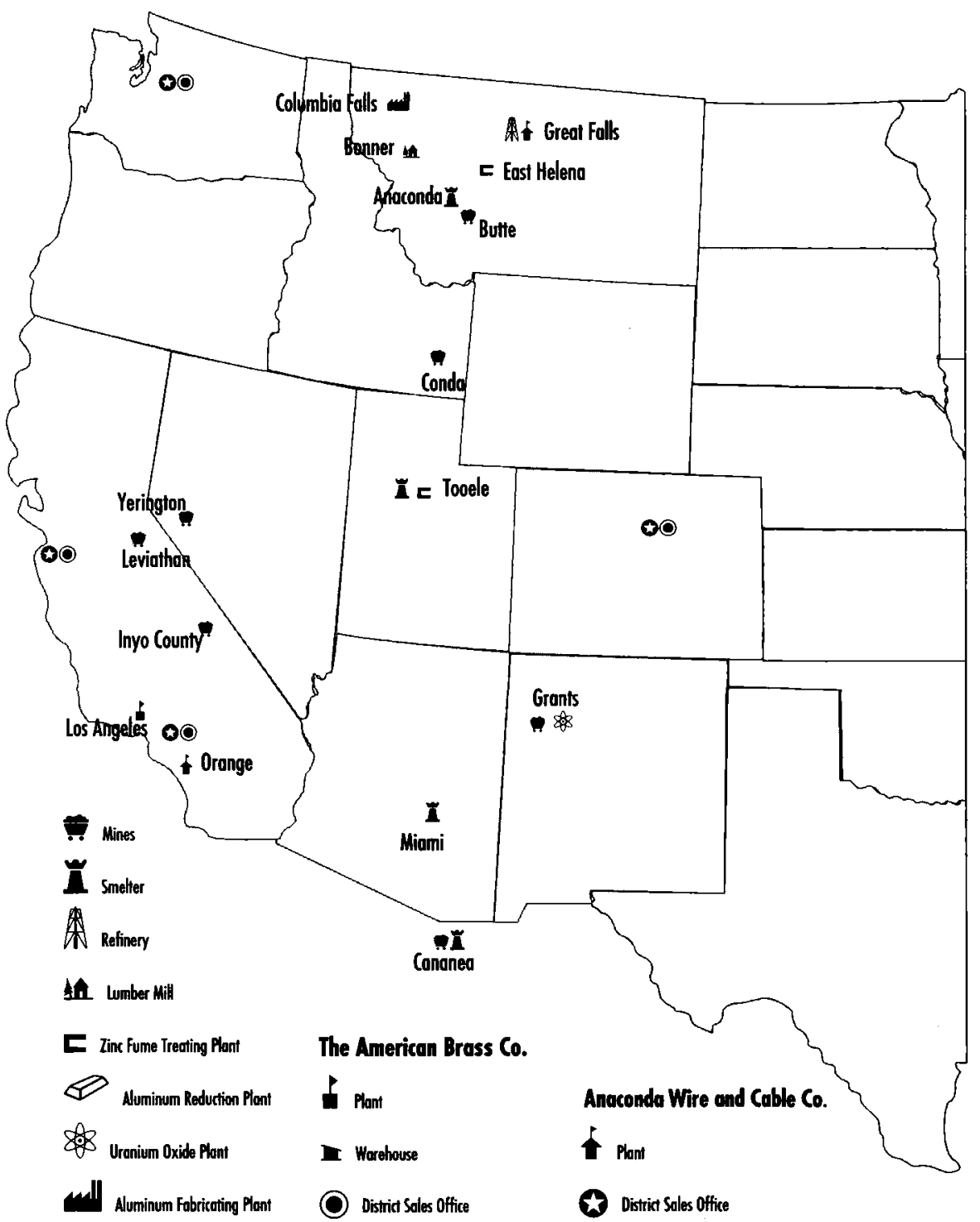

Map I. "This Is Anaconda." Adapted from Anaconda Company Annual Report, r959. Map design by Nick Baker/ArtText. 


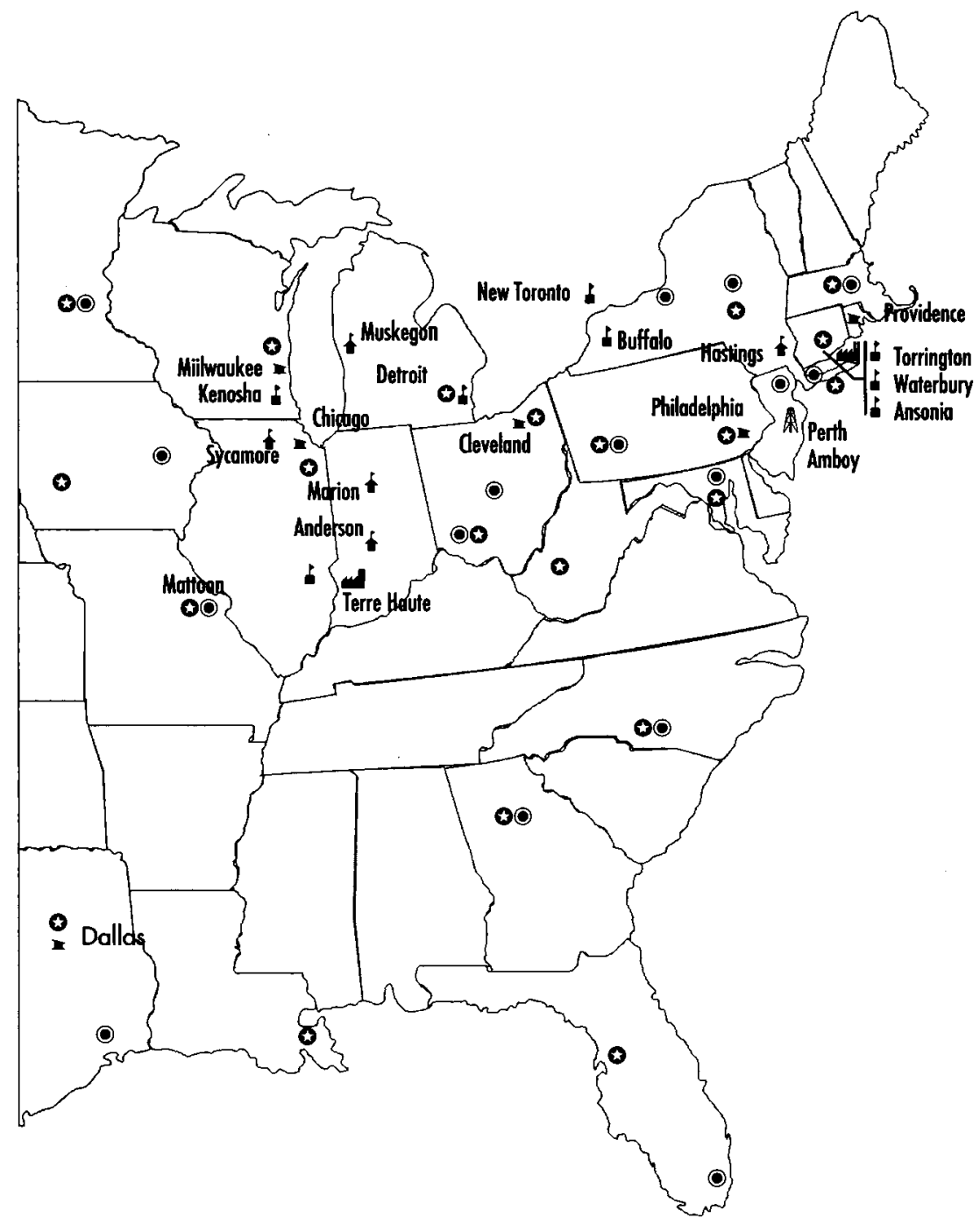




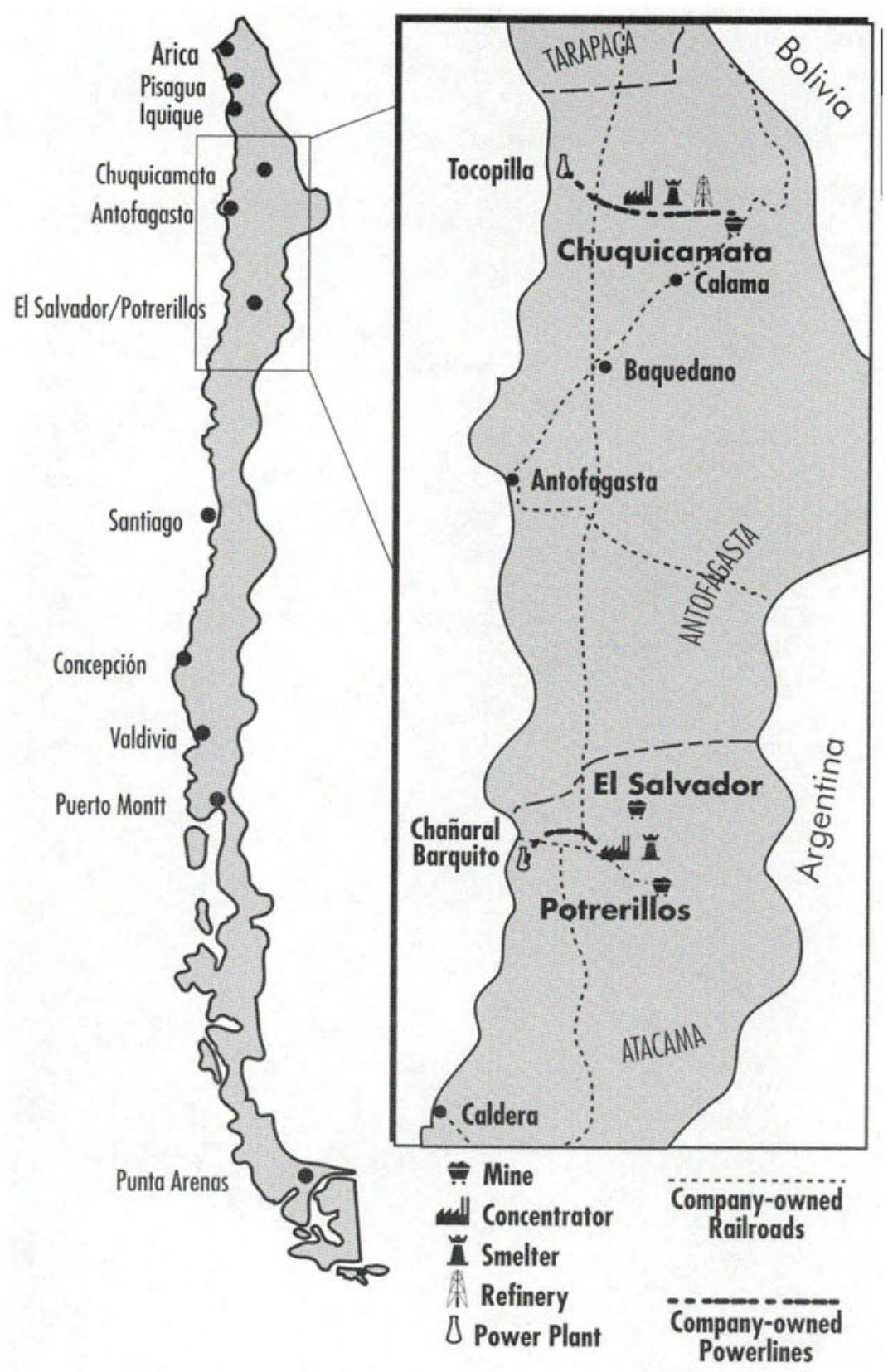

Map 2. "Anaconda Operations in Chile." Adapted from Anaconda Company Annual Report, 1959. Map design by Nick Baker/ArtText. 


\section{Tracing the Veins}

Of Copper, Culture, and

Community from Butte

to Chuquicamata

\section{Janet L. Finn}


University of California Press

Berkeley and Los Angeles, California

University of California Press, Ltd.

London, England

(C) 1998 by

The Regents of the University of California

\section{Library of Congress Cataloging-in-Publication Data}

Finn, Janet L., 1956-

Tracing the veins : of copper, culture, and community from Butte to Chuquicamata/Janet L. Finn

p. $\mathrm{cm}$.

Includes bibliographic references and index. ISBN 0-520-2 I 1 36-7 (cloth : alk. paper). ISBN 0-520-2I I 37-5 (pbk. : alk. paper).

I. Anaconda Company. 2. Copper industry and trade-Social aspects-Montana-Butte.

3. Copper industry and trade-Social aspects Chile-Chuquicamata. I. Title.

HD9539. $\mathrm{C}_{7} \mathrm{U}_{539} \quad 1998$

338.2'743'0978668-dc2I

97-45 I 20

Printed in the United States of America
98
76
$\begin{array}{lllll}5 & 4 & 3 & 2 & \mathrm{I}\end{array}$

The paper used in this publication meets the minimum requirements of American National Standards for Information Sciences-Permanence of Paper for Printed Library Materials, ANSI Z39.48-1984. 
To the women and men of Butte, Chuquicamata, and Calama, who offered me their courage, wit, and wisdom. 

Butte, Montana (1988)

I cannot sleep in this silence.

All my young life I could hear thrumming of the mines beneath my feet. Beneath my bed the rumbling pumps, the feet of my uncles rising and falling, heavy in the shafts. Electric roar of mine yard lights up on the hill where they gave limbs, lungs and finally, lives to the machines and copper dust.

I cannot hear tonight the distant voices of outrage that were the very walls of the Miner's Union Hall. In the end, there was a price the company found for that.

Awake now, I drift ever downward through black, collapsing tunnels. Jobless, I wail and wander beneath the streets, offering poor comfort to the children of this city.

John McGinley 1992 
